\title{
De la iglesia a las calles. \\ La buena prensa navarra y las movilizaciones católicas ante el laicismo liberal (1906-1910)
}

Beatriz Gainza Laset

bgainzalas@educacion.navarra.es

IESNAPA Félix Urabayen

Bartolomé de Carranza, 5

31008 Pamplona

«No basta ser católicos, corremos tiempos en que es de necesidad dar fe de ello». ${ }^{\text {. }}$

Resumen: Este artículo se basa en un análisis de la prensa sobre la cuestión religiosa en el contexto de la primera década del siglo xx en Navarra. A través de dos diarios, el carlista El Pensamiento Navarro y el conservador Diario de Navarra, se trata de ver el papel de la prensa como elemento movilizador en una sociedad de masas y analizar cómo las corrientes políticas que representaban se unieron en un movimiento de protesta unitario contra las medidas laicistas de los gobiernos liberales, en un momento en el que en España se está forjando una nueva identidad católica, de perfil victimista y militante, que se vinculará indefectiblemente a una idea de nación y que será clave para entender las futuras estrategias comunes de conservadores y carlistas.

Palabras Clave: Navarra, I900-1910, prensa, movimiento católico, laicismo.

From the Church to the Streets.

Cood press in Navarre and Catholic mobilization

in the face of Liberal laicism (1906-1910)

АвsтRACт: This article carries out a press analysis of religious conflict in the context of the first decade of the 2oth century in Navarre, Spain. It

I Diario de Navarra, 22/11/1906.

GAINZA, Beatriz, «De la iglesia a las calles. La buena prensa navarra y las movilizaciones católicas ante el laicismo liberal (1906-1910)». Cercles. Revista d'Història Cultural, 23, 119-153. ISSN: 1139-0158. ISSN-e: 1699-7468. DOI: 10.1344/cercles2020.23.1012. Data de recepció: 19/2/2020. Data d'acceptació: $1 / 6 / 2020$. 
focuses on two main newspapers, the Carlist publication El Pensamiento Navarro and the Conservative paper Diario de Navarra, to see how the press was used as a mobilizing tool in mass society, and analyze how the political movements they represented joined against the secularist measures introduced by Liberal governments. In a key moment, at which a new Catholic identity was being formed, this religious victimism and militant profile would be invariably linked to the notion of Spain as a nation, which is essential to understanding future and common strategies used by the Conservative and Carlist movements.

Keywords: Navarre, I900-I9I0, press, Catholic movement, secularism.

A principios del siglo xx, eclosionó en España una serie de transformaciones en las identidades y las formas de movilización política que se reflejaron en el conflicto entre culturas políticas enfrentadas, entre otras cosas, por la cuestión religiosa. En este artículo vamos a analizar el tratamiento de esta cuestión por parte de dos de los principales diarios católicos navarros: El Pensamiento Navarro (carlista) y el Diario de Navarra (conservador cercano al maurismo), prestando especial atención a la respuesta contra la Ley de Asociaciones de 1906 y la Ley del Candado de I9ıo, impulsadas por sendos gobiernos liberales. El objetivo es estudiar, desde el plano regional, cómo ese papel movilizador de la prensa fue conformando una nueva identidad católica, militante, forjada a través de la amalgama de diferentes culturas políticas que se enfrentarán a las pretensiones secularizadoras y que coincidirán, sobre todo, en el nacionalcatolicismo, que en España venía «conformando una cultura política transversal desde mediados del siglo XIX en la que la fe católica se transformaba en el elemento constitutivo de la nación». ${ }^{2} \mathrm{Y}$, ligada a ella, una visión de Navarra

2 J. Louzao, «Nación y catolicismo en la España contemporánea. Revisitando una interrelación histórica», Ayer, 90, 2013, p. 75. Sobre la conformación del nacionalcatolicismo, véase también A. Bоттı, Cielo y dinero. El nacionalcatolicismo en España, I88I-1975, Madrid, 
también unida de manera indefectible a la defensa de la religión católica.

La llamada cuestión religiosa, la pugna entre clericalismo y anticlericalismo, adquirió gran relevancia en la primera década del siglo xx. El clericalismo se ha definido como «la pretensión por parte de la Iglesia católica como tal, o de sus miembros, de mantener o recuperar un papel en la vida pública — fundamentalmente la vida política- de las sociedades modernas o inmersas en el proceso de modernización para amoldarlas a sus propuestas ideológicas, religiosas y morales desde una posición de privilegio y con ánimo de exclusión de otras propuestas». ${ }^{3}$ Trataba, pues, de contrarrestar lo que percibía como un "proceso de descristianización y de secularización». Mientras que, por su parte, el anticlericalismo se puede entender como el rechazo a esa pretensión católica de seguir influyendo en todos los ámbitos de la vida pública, lo que se percibía como una «amenaza a la consolidación de un Estado liberal y secular». Por lo tanto, clericalismo y anticlericalismo serán dos fenómenos contrapuestos que se retroalimentan el uno al otro y «se autojustifican como legítimamente defensivos el uno frente al otro». ${ }^{4}$

Así, cuando los gobiernos liberales comiencen a plantear algunas medidas contrarias a los intereses de la Iglesia, esta animará a sus feligreses a salir del templo y tomar las calles. Una movilización que

Alianza, 1993. Sobre la importancia de la movilización contra el laicismo en el surgimiento de una nueva identidad católica, véase J. De La Cueva, «Católicos en la calle: la movilización de los católicos españoles, I899-I923", Historia y política. La religión y la política, 3, 2000.

3 J. De La Cueva y A. L. López Villaverde J., "A modo de introducción. Reflexiones en torno al clericalismo y al asociacionismo católico», en J. De La Cueva y A. L. López Villaverde (coords.), Clericalismo y asociacionismo católico en España de la Restauración a la Transición: un siglo entre el palio y el consiliario, Cuenca, Universidad de Castilla La Mancha, 2005, p. 22.

4 J. De La Cueva y F. Montero, «Clericalismo y anticlericalismo entre dos siglos: percepciones recíprocas», en J. De La Cueva y F. Montero (eds.), La secularización confictiva. España (I898-193I), Madrid, Biblioteca Nueva, 2007, pp. IOI-IO2.

Cercles. Revista d'Historia Cultural, 23 (2020), 119-153. ISSN: 1139-0158. e-ISSN: 1699-7468. DOI: 10.1344/cercles2020.23.1012. 
incluirá también el uso de nuevas formas de religiosidad, entre las que destacan el impulso de devociones como la del Sagrado Corazón de Jesús o las marianas. ${ }^{5}$ Estos marcos devocionales, como han señalado Joseba Louzao y José Ramón Rodríguez Lago, facilitaban «una autoidentificación nacional y católica de primer orden» y «en el conflicto local adquirieron todo su significado y crearon experiencias de nación concretas». Según estos autores, "a nivel local el conflicto entre clericalismo y anticlericalismo traslucía un enfrentamiento por la definición nacional que hasta el momento ha sido infravalorado». ${ }^{6}$ No hay que perder de vista que el factor local es un elemento clave en la Restauración, ya que las relaciones caciquiles en las que se basaba este sistema también conllevaban la influencia del elemento regional sobre el nacional. ${ }^{7} \mathrm{Y}$ "aun cuando el conflicto entre clericales y anticlericales fuera un asunto de trascendencia general, se desenvolvió a través de dinámicas locales y se fortaleció por estímulos municipales». ${ }^{8}$

5 Sobre el uso de las devociones marianas, véase F. J. Ramón, La virgen del Pilar dice... Usos politicos y nacionales de un culto mariano en la España contemporánea, Zaragoza, Prensas de la Universidad de Zaragoza, 20I4; y R. Di Stefano y F. J. Ramón (eds.), Marian Devotions, Political Mobilization, and Nationalism in Europe and America, Londres, Palgrave-Macmillan, 2016.

6 «Fue en ese ámbito local donde se entremezclaron precisamente las experiencias concretas de nación y religión». J. Louzao y J. R. RodríGuez, «Religión y nacionalización. Una aproximación desde la Historia española», en F. Luengo y F. Molina (eds.), Los caminos de la nación. Factores de nacionalización en la España contemporánea, Granada, Comares, 20I6, pp. 73-74. Sobre el papel de la imaginería católica como recurso en la «modernidad defensiva» de la Iglesia, véase también J. LouzAo, «Las imágenes de lo sagrado o cómo ser católico entre cambios y continuidades (I875-193I)", Historia contemporánea, 5I, 2015.

7 Si se comprende la política de la Restauración "como un gran pacto entre el poder central y las élites locales», se puede ver «la dirección "ascendente" de la vida política, esto es, el influjo de la provincia y del mundo local en el conjunto del país», R. Villares y J. Moreno, Restauración y dictadura, Barcelona, Crítica/Marcial Pons, 2009, p. II5.

8 J. Louzao, «Nación y catolicismo en la España contemporánea. Revisitando una interrelación histórica», Ayer, 90, 2013, p. 78.

Cercles. Revista d'Història Cultural, 23 (2020), 119-153.

ISSN: 1139-0158. e-ISSN: 1699-7468. DOI: 10.1344/cercles2020.23.1012. 
De tal forma que esa nueva identidad colectiva católica se caracterizará por la necesidad de dar continuo testimonio público de fe. Para una Iglesia asustada ante experiencias como las del Sexenio Democrático y ante la creciente indiferencia religiosa de parte de la población española, ya no bastará con la creencia privada y el cumplimiento con los ritos y los preceptos eclesiásticos; la nueva situación requerirá la ocupación constante del espacio público, por lo que se multiplicarán actos como romerías, procesiones, peregrinaciones, actos de desagravio, vigilias, etcétera. Pero, en un contexto de desarrollo de una sociedad de masas, la Iglesia y el movimiento católico adoptarán también, decididamente, las nuevas formas de movilización del liberalismo: mítines, manifestaciones, prensa, recogidas de firmas, etcétera, promoviendo actos públicos multitudinarios, sin descartar para ello esos repertorios de viejas y nuevas formas de religiosidad, dotándolas de una significación militante como muestra de la fuerza del catolicismo, ${ }^{9}$ en un proceso que Joseba Louzao denomina la recomposición religiosa en la modernidad. ${ }^{10}$

Al mismo tiempo, también desde finales del siglo xIx, el carlismo venía impulsando una reorganización interna, liderada por el marqués de Cerralbo, que se tradujo en el fomento de círculos carlistas, periódicos y campañas políticas como los viajes de propaganda a Cataluña y Valencia en I890, o a Navarra y el País Vasco en I891, que, a través de mítines, banquetes, aplecs o diversos tipos de reuniones, servían para reforzar la identidad de grupo. ${ }^{\text {II }}$ Es decir, también se iba

9 F. J. RAMón, «"El catolicismo tiene masas”. Nación, política y movilización en España, I868-I93I", Historia Contemporánea, 5I, 2015, pp. 427-454.

IO J. LouZAO, «La recomposición religiosa en la modernidad: un marco conceptual para comprender el enfrentamiento entre laicidad y confesionalidad en la España contemporánea», Hispania Sacra, I2I, 2008.

II J. CANAL, «La revitalización política del carlismo a fines del siglo xix: los viajes de propaganda del Marqués de Cerralbo", Studia Zamorensia, 3, 1996, pp. 243-272. En esa remodelación, el marqués de Cerralbo daba especial relevancia a la propaganda, ya que, según

Cercles. Revista d'História Cultural, 23 (2020), 119-153. ISSN: 1139-0158. e-ISSN: 1699-7468. DOI: 10.1344/cercles2020.23.1012. 
adaptando con decisión a la nueva sociedad de masas, en la que la movilización de la población era clave. De tal forma que el carlismo se encontraba a principios de siglo con una capacidad movilizadora de sus bases, que, al menos en Navarra, como veremos, sería muy amplia y susceptible de ser utilizada en campañas de movilización católica más generales. Tanto, que pudo contar con el apoyo de las elites conservadoras navarras, que no dudaron en sumarse a los tradicionalistas para lograr una movilización masiva en defensa de una visión nacionalcatólica en la que estaban esencialmente de acuerdo. ${ }^{\text {I2 }}$

Hablamos, en definitiva, de una lucha que va más allá de la cuestión religiosa; se trata de una guerra cultural por los valores que debían definir la identidad del grupo, es decir, por la propia definición de la nación. ${ }^{13}$ A lo largo del siglo xix había ido apareciendo una idea de "ciudadanía católica» que aunaba la comunidad nacional y religiosa en un proyecto de confesionalidad del Estado de perfil excluyente. Otra idea de ciudadanía católica de perfil más liberal, integrador y universalista había fracasado frente a este proyecto absorbido por los sectores conservadores y carlistas. ${ }^{\text {I4 }}$ Para entonces, «el concepto de nación emergido en las revoluciones liberales había sufrido ya algunas modificaciones sustantivas respecto a su sentido original, viéndose sujeto a parámetros más conservadores que incorpo-

sus propias palabras, «hoy es día de reñir esa lucha pacífica de la propaganda, el periódico, la tribuna y la organización». Cit. en J. Canal, El carlismo, Madrid, Alianza, 200o, p. 234.

I2 Véase un claro antecedente de colaboración con protagonismo carlista en la celebración del tercer centenario de la muerte de Teresa de Ávila en I882, en G. Di Febo, «Per uno studio sul terzo centenario della morte di Teresa de Jesús. Il pellegrinaggio mancato e la Giunta contestata», Teresianum, 4I, I990/2, pp. 617-645.

I3 Véanse, por ejemplo, J. De La Cueva, «Movilización política e identidad anticlerical, I898-ı9ıо», Ayer, 27, I997; y J. Louzao, «Nación y catolicismo en la España contemporánea. Revisitando una interrelación histórica», Ayer, 90, 2013.

I4 Véase G. Alonso, "Ciudadanía católica: identidad, exclusión y conflicto en la experiencia liberal hispana», en F. Molina (coord.), Extranjeros en el pasado. Nuevos historiadores de la España contemporánea, Universidad del País Vasco, 2009, pp. 45-72.

Cercles. Revista d'História Cultural, 23 (2020), 119-153. ISSN: 1139-0158. e-ISSN: 1699-7468. DOI: 10.1344/cercles2020.23.1012. 
raban las tradiciones étnicas — sin excluir las religiosas - a una vertiente contrarrevolucionaria surgida frente al ascendente fervor del internacionalismo de clase». ${ }^{\text {I5 }} \mathrm{Y}$, de forma paralela, otras culturas políticas, como las ligadas al republicanismo y al movimiento obrero, iban también desarrollando su propia idea de nación que consideraba la excesiva influencia de la Iglesia como un freno al progreso con el que había que acabar cuanto antes, por lo que el enfrentamiento entre clericales y anticlericales sería creciente, y alcanzó uno de sus momentos más intensos en esos primeros años del siglo xx.

\section{El Diario de Navarra y El Pensamiento Navarro en la Navarra de principios de siglo xx}

Entre los diversos elementos movilizadores que la Iglesia venía tratando de impulsar, cabe destacar la llamada «buena prensa», es decir, la prensa católica, que debía oponerse a la "mala prensa», a la que achacaba, en gran medida, su pérdida de influencia social. ${ }^{16} \mathrm{Y}$ es que, como recogía la revista El Mensajero del Corazón de Jesús y del Apostolado de la Oración, «el párroco predica una vez a la semana y el periódico todos los días de la semana», y, además, «el párroco predica a un puñado de fieles y el periódico a miles de infieles». ${ }^{17}$

I5 J. Louzao y J. R. Rodríguez, «Religión y nacionalización. Una aproximación desde la Historia española», en F. Luengo y F. Molina (eds.), Los caminos de la nación. Factores de nacionalización en la España contemporánea, Comares, 2016, p. 60.

I6 Sobre la «buena prensa» como elemento movilizador católico, véase I. SÁNCHEZ, "El pan de los fuertes: la buena prensa en España», en J. De La Cueva y A. L. López VillaVERDE (coords.), Clericalismo y asociacionismo católico en España de la Restauración a la Transición: un siglo entre el palio y el consiliario, Cuenca, Universidad de Castilla La Mancha, 2005. Hitos importantes en ese proceso fueron las asambleas nacionales de la Buena Prensa, como las celebradas en Sevilla en 1904 y en Zaragoza en 1908. Véanse I. SÁnchez, op. cit., p. 64; y J. M. Gastón, No estamos para bailes rusos. La «buena prensa» navarra ante la revolución bolchevique (I9I7-1923), Tafalla, Txalaparta, 2018, p. 23.

I7 Cit. en I. SÁnCHez, op. cit., p. 55. 
El Diario de Navarra apareció en 1903 con el subtítulo de "periódico independiente» y una logística más moderna que la del resto de la prensa navarra. Frente a la prensa de partido habitual en la época, el Diario presentaba como uno de sus objetivos la imparcialidad ya desde su primer número, ${ }^{18}$ aunque representó siempre los intereses de la oligarquía económica de la provincia, ampliamente representada en su consejo de administración. ${ }^{\text {I9 }}$ Sus miembros estarían, en general, ligados al Partido Conservador de Antonio Maura, aunque también habría representantes de otros sectores de la derecha navarra. Lo que los unía era que no sentían sus intereses bien defendidos por el hasta entonces diario conservador de referencia en la provincia, El Eco de Navarra, considerado demasiado tibio ante la creación, en 1902, de la Federación Local de Sociedades Obreras de Pamplona. En la capital se concentraban 30 ooo de los poco más de 300000 habitantes de una provincia aún sobre todo agrícola. En un contexto duro de amplio paro estacional, hacinamiento, etcétera, los obreros pamploneses estaban empezando a organizarse. El Diario dará la alarma por cómo iban penetrando los postulados socialistas entre ellos, y tratará de promocionar a La Conciliación, una entidad católica creada en 1902 por algunos prohombres de la región (varios de ellos ligados al propio Diario), como una sociedad mixta para dirimir las posibles disputas mediante el arbitraje. ${ }^{20}$

I8 «Venimos sin preocupaciones, ni prejuicios de escuelas ni partidos, con una sed grande de imparcialidad, de verdad y de justicia». Diario de Navarra, 25/2/1903.

I9 «Su núcleo fundacional pertenecía a la burguesía industrial y terrateniente, propietaria de la mayoría de las empresas navarras y, en no pocos casos, de las corralizas de las zonas media y sur de Navarra». J. M. GASTón, No estamos para bailes rusos. La "buena prensa" navarra ante la revolución bolchevique (1917-1923), Tafalla, Txalaparta, 20I8, pp. 26-27.

20 M. M. Larraza, «Pamplona desde el comienzo del siglo xx hasta 1936», en I. Azkona y R. Jimeno, Historia de Pamplona. Recorrido histórico por el pasado de la ciudad, Pamplona, Pamiela, 20I9; y J. Andrés-Gallego, Navarra. Cien años de historia, Pamplona, Diario de Navarra, 2003, pp. 22-23.

Cercles. Revista d'Història Cultural, 23 (2020), 119-153. ISSN: 1139-0158. e-ISSN: 1699-7468. DOI: 10.1344/cercles2020.23.1012. 
En este sentido, para hacer frente a ese incipiente movimiento obrero, así como al anticlericalismo, al republicanismo y a todas las «ideas disolventes» que llegaban a través de la prensa madrileña, apareció el Diario de Navarra, cuyos directores en estos años fueron José Vicente Berazaluce, Eustaquio Echauri y Mario Ozcoidi. A lo largo de este período fue aumentando progresivamente su tirada desde los 2000 ejemplares con que comenzó en 1903 hasta los 4000 de I9I3, en una evolución que lo convertiría en el diario más vendido de la provincia con diferencia. ${ }^{2 \mathrm{~T}}$

El Pensamiento Navarro, por su parte, era el órgano del Partido Carlista, creado en I897 como sucesor de La Lealtad Navarra y con el mismo lema: «Dios, Patria, Rey». Se caracterizó siempre por hacer del catolicismo una de sus banderas de combate, junto a la defensa de la autonomía navarra y de la monarquía tradicionalista. Desde I905 se enorgullecía de ser el único diario navarro con censura eclesiástica (después de que el Diario y el integrista La Tradición Navarra renunciaran a ella tras un conflicto del primero con el obispo José López Mendoza $\left.{ }^{22}\right)$. Y, frente a la pretensión de neutralidad del Diario, El Pensamiento siempre hizo gala de ser un periódico de partido dedicado a la promoción de la causa carlista. Así, en una sección de

2I Á. Zoco, Publicaciones periódicas en Navarra (I900-1940), Pamplona, Gobierno de Navarra, 20I4, pp. 173-183. De sus directores en este período, la figura más destacada fue Eustaquio Echauri, que firmaba como Fradúe diversos artículos de tono corrosivo que le procuraron frecuentes polémicas. En 1906 fue condenado por injurias al rector del seminario y abandonó la dirección, pero siguió escribiendo en el Diario hasta I9IO. R. LAPesQuera, Diario de Navarra, 1903-I908. El despertar del camaleón, Pamplona, Pamiela, 2003.

22 El agustino José López Mendoza fue obispo de Pamplona desde I899 hasta su muerte en 1923, a pesar de sus enfrentamientos con parte de las elites autóctonas, especialmente en los primeros años de su episcopado, por el nombramiento de no navarros para determinados cargos, o por su apoyo al cooperativismo agrario católico. Véanse al respecto R. Lapesquera, op. cit.; y J. GoÑI, Historia de los obispos de Pamplona, XI, Pamplona, Eunsa, 1999. 
diálogos costumbristas y moralizantes llamada «Un rato de conversación», se justificaba el reducido precio del periódico, afirmando: "Ya se vé que el fin de EL PENSAMIENTO no es el negocio, sino la propaganda». ${ }^{23}$ Durante sus veinte primeros años, el periódico carlista tuvo como director a Eustaquio Echave Sustaeta y tiraba unos I80o ejemplares. ${ }^{24}$

Sin embargo, esa menor tirada no debe ocultar la gran capacidad movilizadora que tenía el diario carlista, un medio de partido dirigido a unas bases numerosas, que, además, se podía encontrar en los círculos carlistas que se iban creando, lo que aumentaba su público potencial. ${ }^{25}$ Sin olvidar la gran penetración de este periódico entre el clero navarro. Es elocuente, por ejemplo, la gran cantidad de sacerdotes que aparecen como donantes en la campaña que realiza $E l$ Pensamiento para recaudar fondos para una nueva imprenta. Así, a menudo los púlpitos se podían convertir en una especie de altavoces del periódico amplificando su capacidad de influencia. ${ }^{26}$ En este sentido, en este período no son pocas las quejas por el hecho de que el

23 El Pensamiento Navarro, 31/07/1909.

24 Á. Zoco, Publicaciones periódicas en Navarra (1900-1940), Pamplona, Gobierno de Navarra, 20I4, pp. 316-323. Echave Sustaeta compaginó la dirección de El Pensamiento de I897 a 1917 con otras tareas, como ser elegido concejal de Pamplona en I905, o ser secretario de la Federación Católico Social Navarra entre i9ıo y 1916.

25 Aunque en la última década del siglo XIX solo se habían constituido oficialmente II círculos carlistas en Navarra, entre 1900 y 1910 se inauguraron 18 más, a los que se sumarían otros diez en la década siguiente. M. FerRer, Elecciones y partidos politicos en Navarra durante la segunda República, Pamplona, Gobierno de Navarra, 1992, p. 92. En cualquier caso, conviene tener en cuenta que los círculos eran una fórmula de encuadramiento más adecuada al espacio urbano, menos necesaria en un carlismo de base rural en el que las viejas fórmulas seguían funcionando bien (como probaban los resultados electorales) como el navarro. J. CANAL, Banderas blancas, boinas rojas. Una historia politica del carlismo, Madrid, Marcial Pons, 2006, cap. IV.

26 Casos anteriores de injerencia electoral del clero en Castilla-La Mancha han sido estudiados en J. A. Inarejos Muñoz, «Sotanas, escaños y sufragios. Práctica política y soportes sociales del neo-catolicismo en las provincias castellano-manchegas (I854-1868)", Hispania sacra, vol. 60, núm. 121, 2008, pp. 297-329.

Cercles. Revista d'Història Cultural, 23 (2020), 119-153. ISSN: 1139-0158. e-ISSN: 1699-7468. DOI: 10.1344/cercles2020.23.1012. 
párroco de un lugar pidiera el voto desde el púlpito para un determinado candidato, por lo general carlista. ${ }^{27}$

Se suele retratar a Navarra como el gran bastión carlista, aunque hace tiempo que se sabe que no era tan monolítica. Es cierto que existía un predominio de partidos derechistas, pero no todos eran carlistas, y, además, había también una minoría heterogénea de republicanos, masones y librepensadores. ${ }^{28}$ Gracias al estudio de Ángel García-Sanz Marcotegui, sabemos que las elites económicas de la Restauración en Navarra eran sobre todo liberal-conservadoras, mientras que la preponderancia del carlismo se encontraba entre sectores sociales más humildes. Entre los mayores contribuyentes de la provincia predominaba la filiación al partido conservador dinástico. ${ }^{29}$ Así que la oligarquía navarra de la época tenía, en general, un perfil católico-conservador, más cercano a las posturas mauristas que a las carlistas. Como recoge también M. a Cruz Mina, en Navarra «las familias importantes (o clase dirigente), ni eran ni habían sido carlistas salvo excepciones, por lo que podía constituir un caso en que la ideología y la fuerza política dominante no fuesen las de la clase económicamente dominante» ${ }^{30}$ No obstante, tal y como seña-

27 A ese respecto, Ángel García-Sanz señala que «las posibilidades de los partidos conservadores se redujeron por el gran número de clérigos carlistas que utilizaron su influencia para descalificarlos ante la opinión». Á. GARCíA-SANZ, Caciques y políticos forales. Las elecciones a la Diputación de Navarra (I877-1923), Castuera, 1992, p. 314. Ya a la altura de I928 está constatado que el diario carlista era el más leído por el clero navarro, aun a pesar de que la tirada del Diario era para entonces muy superior. Véase J. Dronda, Con Cristo o Contra Cristo. Religión y movilización antirrepublicana en Navarra, Tafalla, Txalaparta, 20I3, p. IIO.

28 Á. García-Sanz, «Una guía para el estudio de los heterodoxos navarros (I8651939)», Principe de Viana, 26I, 2015, pp. 193-228.

29 Á. García-SANZ, «Élites económicas y políticas en la Restauración. La diversidad de las derechas navarras", Historia Contemporánea, 23, 200I, pp. 577-628.

30 M. C. Mina, «Elecciones y partidos en Navarra (I89i-I923)», en J. L. García Delgado, La España de la Restauración: politica, economía, legislación y cultura, Madrid, S. XXI, I985, p. III. 
la García-Sanz, conviene relativizar las diferencias entre las elites políticas carlistas, conservadoras o liberales, ya que «los intereses comunes [...] les mantenía unidos en lo fundamental», por lo que cuando acababan las campañas estrechaban sus relaciones sin problemas. $^{3 \mathrm{I}}$

\section{La movilización contra las medidas laicistas de 1906 y 1910 en Navarra}

La pugna entre clericales y anticlericales en España estuvo muy influida por lo que ocurrió en la vecina Francia. Allí, aunque el papa León XIII había roto con la condena absoluta del liberalismo impuesta por su antecesor Pío IX y había recomendado a los católicos que se adaptasen al nuevo orden republicano (ralliement), ni él ni su sucesor Pío X pudieron evitar que los gobiernos franceses de principios de siglo aplicaran una serie de medidas laicistas como las leyes de Combes de I9OI y 1904, que limitaban las congregaciones religiosas y expulsaban a los miembros de las no autorizadas (sobre todo las dedicadas a la educación); y la ley de separación de la iglesia y del estado en 1905 , con la consiguiente polémica sobre el inventariado de iglesias. ${ }^{32}$ Lo acontecido en Francia tuvo una gran repercusión en la prensa católica navarra, en la que proliferan las noticias y artículos sobre los sufrimientos de la Iglesia francesa y la valerosa defensa, a veces casi martirial, que de ella hacen sus feligreses. ${ }^{33}$

3I Á. García-SAnz, Caciques y politicos forales. Las elecciones a la Diputación de Navarra (I877-1923), Pamplona, Castuera, I992, p. 326.

32 J. Lalouette, "El anticlericalismo en Francia, I877-1914", Ayer, núm. 27, 1997, pp. $15-38$.

33 Por ejemplo, en El pensamiento Navarro (Io/II/I906), se destaca que ante el intento del gobierno por inventariar la iglesia de su pueblo, el jefe de la familia Cathelineau, "por cuyas venas corre la sangre de sus heroicos mayores», escribió a su ministro para in-

Cercles. Revista d'Història Cultural, 23 (2020), 119-153.

ISSN: 1139-0158. e-ISSN: 1699-7468. DOI: 10.1344/cercles2020.23.1012. 
Inspirado en esas tendencias progresivas europeas que veían en el Estado la principal herramienta de modernización, también en España el Partido Liberal asumirá la necesidad de fortalecer el poder civil frente al religioso, ${ }^{34}$ planteando una serie de reformas, como permitir los matrimonios y los entierros civiles, o, sobre todo, los proyectos para regular las asociaciones religiosas en 1906 y 1910. En 1906, durante el breve gobierno de José López Domínguez, se elaboró el proyecto de Ley de Asociaciones, que pretendía aplicar la Ley de Asociaciones de 1887 a las congregaciones religiosas. Lo presentó el ministro de Gobernación Bernabé Dávila, aunque nunca llegó a aprobarse debido a la fuerte oposición generada. En I9Io, durante el gobierno más largo de José Canalejas, se proyectó la conocida como Ley del Candado, presentada por el propio presidente, que buscaba que el ministerio de justicia pudiera controlar el número y la composición de las asociaciones religiosas. La ley se aprobó, pero debía ser ratificada a los dos años, cosa que no sucedió por la gran movilización católica generada y por el propio asesinato de Canalejas en I9I2.

El ambiente conflictivo en torno a la denominada cuestión religiosa se dio también en Navarra, sobre todo en Pamplona, donde la presencia republicana se reflejaba incluso en el ayuntamiento. ${ }^{35}$ Cabe destacar el enfrentamiento entre el periodista republicano Basilio Lacort y el obispado, ${ }^{36}$ y el rechazo generado por la representación de

formarle de que ofrecería resistencia y que si se presentaba con quinientos hombres, «él le prometía esperarle a la puerta con otros tantos y se vería si lograba entrar».

34 R. Villares y J. Moreno, Restauración y dictadura, Crítica/Marcial Pons, 2009, p. 384 .

35 Á. García-SAnZ, Las elecciones municipales de Pamplona en la Restauración, Pamplona, Gobierno de Navarra, I990, pp. 53-58.

36 Basilio Lacort fue un pionero del republicanismo y el anticlericalismo en Navarra a través de semanarios como El Porvenir Navarro o La Nueva Navarra. Véase J. M. LeceA, La Vieja Navarra y La Nueva Navarra, Pamplona, Artes Gráficas, I973; y Á. García-SANZ, "Nuevas noticias sobre Basilio Lacort, sus empresas periodísticas y La pelea», Príncipe de Viana, anejo 5, 1986. 
la obra teatral Electra en I90I. ${ }^{37}$ Estos hechos, a veces ligados a incidentes callejeros, junto a la alarma generada por las noticias de los avances anticlericales en Francia, fueron ya forjando esa identidad católica defensiva y militante, dispuesta a tomar las calles si alguien en España decidía imitar el ejemplo francés. Las multitudinarias manifestaciones católicas que se dieron en Pamplona en esos años son una prueba de la eficacia movilizadora de dicha identidad.

La primera tuvo lugar el domingo 9 de diciembre de 1906 en contra del mencionado proyecto de Ley de Asociaciones Religiosas. Estuvo promovida por el recién creado Consejo Diocesano de Corporaciones Católico-Obreras de Navarra, que creó una Junta en Pamplona para organizar dicha manifestación, compuesta por los principales representantes del catolicismo seglar, con predominio de tradicionalistas. ${ }^{38}$

La prensa católica preparó el terreno los días previos mediante diversos discursos movilizadores. ${ }^{39}$ Muchos artículos se caracterizan por denunciar la existencia de un complot de masones, judíos, republicanos, etcétera, para atacar a la Iglesia, impedir su labor social y recortar sus derechos, tanto naturales como constitucionales. De hecho, esgrimirán la razón del origen de sus derechos aludiendo a la legalidad vigente cuando les convenga, o argumentando la prepon-

37 Véase R. Lapesquera, Navarra insólita, Pamplona, Pamiela, 1984, pp. 35-45, así como M. PÉrez Ledesma, «La sociedad española, la guerra y la derrota», en J. PAN-MoNTojo, Más se perdió en Cuba, Madrid, Alianza, 1998, pp. 9I-I50, y "José Nakens (I84I-I926). Pasión anticlerical y activismo republicano», en I. Burdiel y M. Pérez Ledesma, (eds.), Liberales, agitadores y conspiradores. Biografias heterodoxas del siglo XIX, Madrid, Espasa Calpe, 2000, pp. 30I-330.

38 Puede verse la composición de dicha comisión organizadora, por ejemplo, en Diario de Navarra, 4/12/1906. De I7 miembros contabilizamos al menos io carlistas o integristas.

39 En el resto del país se habían movilizado los católicos desde el intento fallido de regicidio del 3I de mayo de i906. Véase E. SAnabria, Republicanism and Anticlerical Nationalism in Spain, Nueva York, Palgrave-Macmillan, 2009, pp. IOI-I22.

Cercles. Revista d'Història Cultural, 23 (2020), 119-153.

ISSN: 1139-0158. e-ISSN: 1699-7468. DOI: 10.1344/cercles2020.23.1012. 
derancia del poder divino sobre el civil cuando no les quede otra opción. Y, ante todo, se insistió en que la manifestación debía servir para que la católica Navarra fuera la vanguardia de la reconquista espiritual de España, ya que «los católicos todos nos miran como una nueva Covadonga de donde ha de partir la Cruzada que arroje a los modernos sarracenos». ${ }^{40}$ Para remarcar el carácter foral de la manifestación, se llegó a proponer aprovecharla para la inauguración del Monumento a los Fueros, recientemente construido para conmemorar las manifestaciones populares de la Gamazada. ${ }^{4 \mathrm{I}}$ Por último no se produjo, pero el monumento jugó un papel simbólico importante tanto en este acto como en el que veremos en i9io. De hecho, en la propia alocución escrita para movilizar a la participación en la manifestación de 1906 se hace una referencia explícita a que «no hace muchos años todavía Navarra, en apretadísimo haz unida, por medio de imponentes manifestaciones, de perdurable memoria, contrarrestó y desbarató los proyectos antifueristas del Gobierno. Suena la hora de que se repita tan magnánima actitud». ${ }^{42}$ Ambos diarios siguieron apelando a lo ocurrido en Francia como ejemplo, tanto del peligro que acechaba como de la labor de resistencia que era precisa. Y publicaron múltiples protestas contra el proyecto de Ley de Asociaciones, en las que cabe destacar la separación de género acorde a los valores sociales dominantes. A la propia manifestación acudirían solo hombres. Y las mujeres expresarían su queja en manifiestos separados, como el destinado a otra mujer, la

40 El Pensamiento Navarro, 9/12/1906.

4I La Gamazada fue la protesta popular fuerista de I893-1894 contra el intento de aumentar el cupo que Navarra pagaba al Estado, véase M. M. LARrAZA, La Gamazada. Ocho estudios para un centenario, Pamplona, Eunsa, 1996. El monumento se había terminado en 1903, pero no llegó nunca a inaugurarse. Sobre el marcado simbolismo de dicho monumento, véase J. UGARTE, La nueva Covadonga insurgente. Orígenes sociales y culturales de la sublevación de 1936 en Navarra y el País Vasco, Madrid, Biblioteca Nueva, I998, p. 33I. 42 Diario de Navarra, 6/12/1906.

Cercles. Revista d'Història Cultural, 23 (2020), 119-153. ISSN: 1139-0158. e-ISSN: 1699-7468. DOI: 10.1344/cercles2020.23.1012. 
reina, indicando su deseo de mostrar su protesta aún a riesgo «de sacrificar la natural modestia de nuestro sexo, no habituada a actos públicos y colectivos». ${ }^{43} \mathrm{Y}$, por supuesto, destacan los apoyos de la jerarquía eclesiástica a las movilizaciones. Como la circular del prelado de Pamplona, López Mendoza, que aunque lamentaba no poder asistir a la manifestación, animaba a todos sus feligreses a acudir a ella. ${ }^{44} \mathrm{O}$, en un tono más combativo, la extensa pastoral del obispo de Santander, publicada a lo largo de varios días en El Pensamiento Navarro, en la que incide en la necesidad de defender a la Iglesia, insinuando que, si es preciso, se emplee la fuerza contra los ataques de la "coalición anticristiana». ${ }^{45}$

Una vez realizada la movilización, insistirán en su éxito, superando la asistencia a la gran manifestación de la Gamazada del 4 de junio de I893, según remarcaron los organizadores. La asistencia la cifra en 40000 personas El Pensamiento Navarro y en 50 ooo el Diario de Navarra, que calificó a los participantes como «juramentados, reconquistadores de la caridad y la fuerza de la santa fé». ${ }^{46}$ Las cifras son casi con seguridad exageradas, ${ }^{47}$ pero dan una idea de lo masiva que fue, especialmente si se tienen en cuenta los números proporcionados en el caso de las manifestaciones convocadas en otras ciuda-

43 El Pensamiento Navarro, 5/12/1906. Las cursivas son mías.

44 Diario de Navarra, 28/1I/1906.

45 Entre el 24/10 y el I3/II/1906. El obispo de Santander era entonces Vicente Santiago Sánchez de Castro. Sobre esta cuestión y la situación en Cantabria, véase J. De LA Cueva, Clericales y anticlericales, el conflicto entre confesionalidad y secularización en Cantabria (I875-1923), Santander, Asamblea Regional de Cantabria/Servicio de Publicaciones de la Universidad, 1994.

46 Diario de Navarra, II/12/1906.

47 Era más que toda la población pamplonesa del momento. Aunque viniera gente de toda la provincia, teniendo en cuenta, además, que solo participaban hombres, la cifra resulta algo inverosímil. El Demócrata Navarro rebajó la cifra a 8000. Cit. en Á. GarcíaSAnZ, «Una guía para el estudio de los heterodoxos navarros. I865-1939", Príncipe de Viana, 26I, 2015 , p. 212.

Cercles. Revista d'História Cultural, 23 (2020), 119-153. ISSN: 1139-0158. e-ISSN: 1699-7468. DOI: 10.1344/cercles2020.23.1012. 
des, de las cuales la pamplonesa es la más numerosa, superior a las de grandes ciudades como Barcelona o Bilbao ${ }^{48}$ Tras la manifestación hablaron el carlista Juan Vázquez de Mella, el integrista Ramón Nocedal y el conservador Francisco Javier González de Castejón, marqués de Vadillo. Y se leyó una declaración, escrita por Arturo Campión, ${ }^{49}$ en la que se denunciaba que la ley violaba «el derecho natural, el constitucional y el divino», por lo que era necesario que «volviera a las logias que la engendraron». Pamplona, «ciudad cristianísima y cansada de las demasías de cuatro blasfemos idiotas, tenía que rechazarla por todos los medios»..$^{50}$ Tras la manifestación se produjeron algunos incidentes entre clericales y anticlericales, por los que el Diario exigiría la dimisión del alcalde, el liberal Joaquín Viñas Larrondo. Y el domingo siguiente, los anticlericales navarros organizaron una manifestación de respuesta, ridiculizada por la prensa católica por su escasa asistencia.

Finalmente, el proyecto de ley fue paralizado y los liberales fueron desalojados del gobierno al año siguiente; pero regresarían poco después, en un ambiente conmocionado por la Semana Trágica de 1909, con ansias laicistas renovadas que se plasmaron en la mencionada Ley del Candado del presidente José Canalejas. Contra esa ley se daría la otra gran manifestación católica el domingo 2 de octubre de i9ı. Los obispos españoles mostraron su rechazo a dicha ley y se fue organizando por todo el Estado un movimiento de protesta liderado por múltiples asociaciones católicas, como la recién creada Asociación Católico Nacional de Propagandistas. En Navarra jugaría un papel clave la Federación Católico Social Navarra, que se acababa de

48 J. Andrés-Gallego y A. Pazos, La Iglesia en la España contemporánea, Madrid, Encuentro, 1999, p. 267.

49 Escritor y político pamplonés que pasó por diferentes corrientes políticas (diputado integrista en la época de la Gamazada, se aproximaría más tarde al nacionalismo vasco), priorizando siempre la defensa del foralismo y el catolicismo.

50 Diario de Navarra, II/I2/1906.

Cercles. Revista d'Història Cultural, 23 (2020), 119-153. ISSN: 1139-0158. e-ISSN: 1699-7468. DOI: 10.1344/cercles2020.23.1012. 
fundar para agrupar las diversas obras sociales católicas creadas por toda la provincia con el apoyo del clero rural y el carlismo, continuando la labor del Consejo Diocesano de Corporaciones CatólicoObreras de Navarra. La propia Junta de Defensa, organizada para «dirigir los esfuerzos del país» en la defensa de la Iglesia, estaba presidida por Fernando Gorosábel, vicepresidente de la FCSN. ${ }^{51}$

Ya durante el verano, en el marco de ese amplio movimiento de protesta, El Pensamiento Navarro había lanzado la idea de realizar una gran manifestación contra la ley para el 7 de agosto enfrente de la residencia veraniega de Alfonso XIII en San Sebastián. Pero el gobierno de Canalejas lo prohibió por temor a que la protesta derivara en un levantamiento armado, y amenazó con enviar al ejército. Aun así, los carlistas acudieron y hubo detenidos.

El ambiente era cada vez más crispado. El nuevo gobierno liberal estaba yendo más lejos que en 1906, y se había producido incluso la ruptura de relaciones con el Vaticano, lo que fue utilizado en la cobertura de ambos diarios, en la que pervive la idea del complot masónico orquestado desde París. Y se subraya el peligro de otras medidas laicistas, como la ley del matrimonio civil. Y, sobre todo, las reformas educativas, que se consideran un paso para crear «una generación atea», y son sentidas como «una verdadera humillación para los católicos»; sería como "escupirnos a la cara a la inmensa mayoría de los españoles». ${ }^{52}$ Hay incluso un recrudecimiento de las campañas de desprestigio personal, atacando duramente a determinadas personalidades del gobierno, ya sea el propio Canalejas o sus

5I El Pensamiento Navarro, 29/5/1910 y 7/8/1910. El resto de miembros eran, al igual que en 1906 , prohombres del catolicismo seglar con predominio tradicionalista. De 7 miembros, 6 eran carlistas o integristas, o al menos habían participado en candidaturas carlistas al ayuntamiento de Pamplona, como el exalcalde Gorosábel, quien también había sido secretario de la Diputación Foral.

52 El Pensamiento Navarro, 6/7/1910.

Cercles. Revista d'Història Cultural, 23 (2020), 119-153.

ISSN: 1139-0158. e-ISSN: 1699-7468. DOI: 10.1344/cercles2020.23.1012. 
ministros, y también a representantes locales como el alcalde de Pamplona, que volvía a ser el liberal Joaquín Viñas.

En ese contexto se planteó una serie de grandes actos católicos simultáneos por toda España para el 2 de octubre. ${ }^{53}$ Para la manifestación navarra se insistió en la necesidad de dejar fuera las divisiones políticas dentro de los católicos: «[...] cada cual que guarde sus ideales políticos y su bandera para otra ocasión. En la presente no hay más bandera que la del Vaticano, ni más Caudillo que Pedro, ni más intereses que salvar que los de la Iglesia». ${ }^{54}$ Ambos diarios publicaron continuas adhesiones de los pueblos que se suman a la manifestación. Destacan aquellos que tienen alguna dificultad para asistir, pero que la superan por su fervor religioso. 55 Acudió la mayoría de los ayuntamientos en corporación con sus estandartes, y en el planteamiento de la marcha se quiso subrayar el foralismo, estableciendo que, al pasar por el Monumento a los Fueros, se dividiera en dos bloques, dejando la estatua en medio de ambos y descubriéndose los manifestantes la cabeza a su paso por el monumento en señal de respeto. ${ }^{56}$

Y, de nuevo, cabe destacar la discriminación de la mujer en la organización. Lo señalaría de manera explícita El Pensamiento Navarro en un artículo titulado "Los hombres a la manifestación, las mujeres a la oración». ${ }^{57}$ Incluso hay testimonios de mujeres que,

53 Para el contexto peninsular y sus precedentes, pueden consultarse V. CÁrCel ORTí, «Precedentes histórico-jurídicos de la ley "del Candado”: documentación diplomática esencial de 1876 a I910", Analecta sacra tarraconensia, Revista de ciències historicoeclesiàstiques, 76, 2003, pp. 315-492; y M. A. GARCía De JuAN, «Política, religión y enseñanza en España en el año de la Ley del "Candado", ı9ıо: decisiones gubernamentales, debates y controversias", Revista agustiniana, I80, 2018, pp. 393-438.

54 Carta de Francisco M. Melgar (exsecretario del pretendiente D. Carlos) en El Pensamiento Navarro, 27/9/1910.

55 Por ejemplo, Morentin en Diario de Navarra, 29/9/1910.

56 El Pensamiento Navarro, 2/10/1910.

57 El Pensamiento Navarro, 30/9/1910. Además, subrayando la feminidad del esquema, esas oraciones irían destinadas a la virgen.

Cercles. Revista d'Història Cultural, 23 (2020), 119-153. ISSN: 1139-0158. e-ISSN: 1699-7468. DOI: 10.1344/cercles2020.23.1012. 
queriendo acudir, no se les permitió hacerlo, como en el caso del pueblo de Aberin, donde todos los varones mayores de trece años iban a ir, "costando mucho trabajo disuadir a las mujeres que querían venir a la manifestación». ${ }^{58}$ Sin embargo, siempre han existido clases y, tal y como se recogía en la fotografía de la cabecera de la manifestación, algunos de los hombres preeminentes que la encabezaban estaban acompañados de sus familiares, incluidas las mujeres. Mientras que en fotos del resto de la marcha no se aprecia presencia femenina. ${ }^{59}$

Finalmente, la manifestación fue un gran éxito de convocatoria, y la prensa católica cifró la asistencia en 90000 personas. ${ }^{60}$ Aunque la cifra casi con seguridad es de nuevo exagerada (casi doblaba la cifra de 1906, con un recorrido similar y, según la propia prensa convocante, de una duración parecida ${ }^{6}$ ), el éxito de la convocatoria es innegable.

58 Diario de Navarra, 28/9/19010.

59 Las fotografías pueden verse en el semanario La Avalancha, 374, 8/10/1910. Sobre la relación entre mujeres y militancia católica, veánse R. MínGUEZ, «Entre el hogar y la calle. La movilización política de mujeres católicas durante el Sexenio Democrático", Hispania Nova: Revista de historia contemporánea, I8, 2020, pp. 419-449; y Evas, Marias y Magdalenas: género y modernidad católica en la España liberal (I833-I874), Madrid, CEPC/ Asociación de Historia Contemporánea, 2016; e I. Blasco, Paradojas de la ortodoxia. Politica de masas y militancia católica femenina en España (1919-1939), Universidad de Zaragoza, 2003, pp. 7-34.

60 La Avalancha elevaba la cifra incluso a Ioo ooo y subrayaba la necesidad de que toda España siguiera el ejemplo navarro para salvarse: «Si España se navarriza, España se salva». Cit. en Á. García-SANZ, "Una guía para el estudio de los heterodoxos navarros (I865-1939)", Príncipe de Viana, 26I, 2015.

6I Según lo publicado tanto por Diario de Navarra como por El Pensamiento Navar$r o$, la diferencia de duración es de I5 minutos ( 2 h en 1906 y 2 h Is en 1910), tiempo muy escaso para un incremento tan espectacular de participantes. Si a esto se le añade que la manifestación estaba compuesta prácticamente en su totalidad por hombres y que toda Navarra contaba en esa fecha con una población absoluta de poco más de 300 ooo personas, aún resulta más complicado admitir esas cifras.

Cercles. Revista d'História Cultural, 23 (2020), 119-153.

ISSN: 1139-0158. e-ISSN: 1699-7468. DOI: 10.1344/cercles2020.23.1012. 


\section{Análisis comparado de la cobertura de El Pensamiento Navarro y Diario de Navarra}

Las dos cabeceras analizadas representaban las dos principales corrientes políticas (que no exclusivas, claro está) de la región: el tradicionalismo carlista de El Pensamiento Navarro y el conservadurismo maurista del Diario de Navarra. Ambas en el espectro político de la derecha, con muchos elementos en común, pero también con importantes diferencias. Al respecto, Ángel García-Sanz ha señalado que las principales diferencias entre carlistas y conservadores serían la aceptación de algunos elementos del liberalismo por parte de los conservadores (o, al menos, la percepción que los carlistas tenían de ello), la mayor propensión carlista al uso electoral de la defensa de la religión, la apelación a la utilización de la fuerza por parte carlista, algunas diferencias en la percepción de la cuestión social (por la extracción popular de las bases carlistas), el rechazo de los carlistas a la dinastía reinante y su mayor beligerancia contra el sufragio universal. ${ }^{62}$

Esas diferencias se perciben incluso a propósito de una cuestión como la defensa de los intereses de la Iglesia, en la que ambas publicaciones estaban totalmente de acuerdo. Por ejemplo, la cuestión dinástica se ve reflejada cuando El Pensamiento echa en cara a Alfonso XIII su responsabilidad ante la posibilidad de que se esté discutiendo la Ley de Asociaciones, y declara de manera abierta que ellos solo deben obediencia al papa y los obispos en lo religioso, y a D. Carlos y sus legítimos representantes en lo político. ${ }^{63}$ Mientras que en el Diario de Navarra, por el contrario, podemos encontrar críticas a los

62 Á. García-SANZ, «Élites económicas y políticas en la Restauración. La diversidad de las derechas navarras", Historia Contemporánea, 23, 2001, pp. 605-613.

63 El Pensamiento Navarro, 28/11/1906. 
carlistas por no apoyar al rey y por impedir la unión política de todos los católicos contra la revolución. ${ }^{64}$

El rechazo carlista a la unidad política católica es otra diferencia notable entre ambos medios. En un momento en el que los tradicionalistas se sienten fortalecidos a nivel político por cómo han logrado monopolizar la movilización contra las medidas de los gobiernos liberales, deciden impulsar una Alianza Católica Antiliberal de carlistas, integristas y católicos independientes, ${ }^{65}$ que se impondrá con rotundidad tanto en las elecciones provinciales como en las elecciones a cortes, en detrimento de los conservadores dinásticos que habían quedado marginados de la coalición. ${ }^{66} \mathrm{El}$ ascenso electoral carlista se dio siempre en los momentos de mayor tensión religiosa. De hecho, en las elecciones de I9I4, con la cuestión religiosa más apagada, la Coalición Católica Antiliberal desaparecería. ${ }^{67}$

$\mathrm{Al}$ respecto, desde el Diario de Navarra se insistirá en la necesidad de unir a los católicos navarros en todas las elecciones, tal y

64 Por ejemplo, en el artículo de Arturo Campión, recogido del Diario Vasco, en Diario de Navarra, 20/9/19Io.

65 El origen de dicha coalición se encontraba precisamente en el simbólico abrazo que el carlista Vázquez de Mella y el integrista Nocedal, ambos diputados a cortes por Navarra, se habían dado en la estación de Tafalla el in de diciembre de 1906, al regreso de la manifestación católica de Pamplona.

66 Resulta revelador lo perjudicados que resultaron los conservadores. En las elecciones a cortes de 1907 y I9IO solo obtuvieron un diputado (siendo los otros 6 para la alianza antiliberal), y en todo el período I905-1916 solo consiguieron 4 diputados forales (por 15 carlo-integristas). También en las elecciones municipales de Pamplona, el hecho de dejar de ir de la mano de los carlistas supuso que no obtuvieran ningún concejal ni en 1909 ni en I9I3. Á. GARCía-SAnZ, Caciques y políticos forales. Las elecciones a la Diputación de Navarra (I877-1923), Castuera, I992; y "Élites económicas y políticas en la Restauración. La diversidad de las derechas navarras», Historia Contemporánea, núm. 23, 200I, p. 615 .

$67 \mathrm{Al}$ romper los carlistas su alianza con unos integristas debilitados por sus fugas hacia el maurismo y el nacionalismo vasco. Además, los tradicionalistas perderían peso ante un frente anticarlista de liberales y conservadores. 
como venía recomendándose sin éxito desde el Vaticano. ${ }^{68} \mathrm{El}$ diario conservador argumentaba que «los elementos católicos que dispersos nada preocupan al enemigo, unidos en apretado haz fácilmente lo tendrían a raya». ${ }^{69}$ Mientras que desde El Pensamiento Navarro se acusará a quienes querían conformar una unidad electoral católica de buscar el fin del carlismo. Y así, mientras el Diario procuraba tratar a los carlistas con respeto, El Pensamiento mirará a los conservadores con cierto desprecio, criticando con dureza a sus líderes, como Antonio Maura, y tachándolos a veces de cobardes. Como cuando en "Un rato de conversación», ante la pregunta sobre la razón por la que, siempre que hay palos, los católicos heridos suelen ser carlistas, la respuesta es bien clara: «Porque los carlistas son los que más se meten a defender las ideas católicas», y, en el momento más crítico, los conservadores "se retiran prudentemente». ${ }^{70}$

Porque también se perciben diferencias con respecto a la violencia. La alusión a ella es constante en el caso de El Pensamiento, tanto a la violencia pasada (la heroica de las guerras del siglo XIX) como a una posible violencia futura, como la que sugería el diputado Joaquín Llorens en un discurso en el círculo carlista de Pamplona: «Si hay ley de Asociaciones, habrá cañones y fusiles». A lo que su compañero Vázquez de Mella "pidió a los asistentes juramento de que sabrán defender hasta con sus vidas la Religión católica». ${ }^{71}$ Además, el uso de la fuerza venía legitimado desde algunas instancias eclesiás-

68 El uso electoral de la defensa de la religión por parte del carlismo hacía tiempo que preocupaba en la jerarquía católica. Ya en I882, el cardenal Miguel Payá expresaba en una carta privada al nuncio Bianchi que el partido carlista se caracterizaba por «explotar el sentimiento católico nacional en provecho de su causa política» y que "el interés de la Religión en España demanda que la suerte de la Yglesia no esté identificada con la de ningún partido", cit. en en R., Villares y J. Moreno, Restauración y dictadura, Barcelona, Crítica/Marcial Pons, 2009, p. 59.

69 Diario de Navarra, 22/II/1906.

70 El Pensamiento Navarro, 5/3/1910.

71 El Pensamiento Navarro, II/I2/1906.

Cercles. Revista d'Historia Cultural, 23 (2020), 119-153. ISSN: 1139-0158. e-ISSN: 1699-7468. DOI: 10.1344/cercles2020.23.1012. 
ticas, como la mencionada pastoral del obispo de Santander ${ }^{72}$ en un tono belicoso que contrastaba con la alocución del obispo de Pamplona publicada por el Diario en la que se llamaba al orden y al respeto a los poderes constituidos. ${ }^{73}$

Aunque, a propósito de las manifestaciones de 1906 y I9Io, El Pensamiento Navarro apeló incluso más que el Diario a la necesidad de mantener el orden (quizás porque sus lectores fueran más proclives a romperlo), siempre dejó patente que, si los medios legales no bastaban para paralizar esas leyes, no descartaban la violencia, recordando: «¿Quiénes son capaces en España de ir a la guerra civil por defender los derechos religiosos? Los carlistas y nada más que los carlistas. Esto lo sabe el mundo entero. Los católicos no carlistas se contentarían con elevar exposiciones respetuosas». ${ }^{74}$

También existían diferencias patentes en la percepción que ambos medios tenían de la cuestión social. El hecho de que gran parte de la base carlista fuera de extracción social humilde se reflejaba en un enfoque más comprensivo con las demandas de los trabajadores ${ }^{75}$ que el del Diario, en cuyo consejo de administración se sentaba gran parte de la oligarquía local. Desde las páginas del Diario se defenderá, por ejemplo, que el problema no era el salario de los obreros, sino el hecho de que les había arrebatado su fe, «manantial de conformi-

72 El Pensamiento Navarro, 7/11/1906.

73 Diario de Navarra, 28/II/1906.

74 El Pensamiento Navarro, I3/II/1906. Al respecto, el propio Maura había puesto sobre la mesa en el congreso el peligro de que el proyecto de Ley de Asociaciones provocase una guerra civil.

75 Aunque, tal y como advierte Jordi Canal, la preocupación carlista «por la llamada cuestión social terminó materializándose en el mutualismo [...] y en la caridad. Unas respuestas que, a la postre, demostrarían ser del todo insuficientes». J. CANAL, El carlismo, Madrid, Alianza, 2000, p. 249.

Cercles. Revista d'Història Cultural, 23 (2020), 119-153. ISSN: 1139-0158. e-ISSN: 1699-7468. DOI: 10.1344/cercles2020.23.1012. 
dad y sin la cual no se conciben las desigualdades sociales». ${ }^{76} \mathrm{La}$ utilización de la doctrina cristiana para justificar la desigualdad social será constante en el diario conservador; por ejemplo, para criticar el nacimiento del movimiento cooperativista agrario católico, defendido sin embargo, desde El Pensamiento. ${ }^{77}$

Para los carlistas, la Iglesia es el núcleo que articula su sociedad ideal, como la reflejada en una tira semanal de El Pensamiento Navarro titulada "Un rato de conversación", escrita por Altobiscar, seudónimo del director, Eustaquio Echave Sustaeta. En ella, un trabajador del campo, José Miguel, siempre preocupado por cumplir con sus obligaciones, es aleccionado de modo paternalista por el señorito (se le denomina así, no aparece su nombre). José Miguel, por supuesto, participó en la última guerra carlista y siempre está dispuesto a acatar lo que se le diga. La jerarquía existe y es muy marcada, pero el señorito y el trabajador viven en armonía porque se respetan el uno al otro. ${ }^{78}$

Este tipo de narraciones didáctico-moralizantes están presentes en ambos medios, e ilustran bien sus diferentes preocupaciones sociales. En el caso de El Pensamiento, el villano suele ser un liberal-demócrata que abusa de sus trabajadores, que no acata ni los más mínimos estándares de justicia social o incluso piedad, dejando la igualdad solo para sus discursos y no importándole dejar a su obrero en la indigencia. Le falta responsabilidad y caridad cristiana. ${ }^{79}$ Mientras que, en el

76 Diario de Navarra, 3/9/1910. "El discurso dominante de la Iglesia española legitimaba la desigualdad social y sacralizaba la propiedad privada, lo que la convertía en una especie de religión de la contrarrevolución». J. Dronda, Con Cristo o Contra Cristo. Religión y movilización antirrepublicana en Navarra, Tafalla, Txalaparta, 2013 , p. 88.

77 Véanse, al respecto, J. Dronda, op. cit., pp. I53-I6o; R. Lapesquera, Diario de Navarra (1903-1908). El despertar del camaleón, Pamplona, Pamiela, 2003, pp. I67-226.

78 Se trata de una tira que se publicaba semanalmente; a modo de ejemplo se puede ver 27/3/1909, 5/2/1910, 6/9/1910, 27/9/1910, 8/10/1910, etcétera.

79 Por ejemplo, en El Pensamiento Navarro, I4/II/1906.

Cercles. Revista d'Historia Cultural, 23 (2020), 119-153. ISSN: 1139-0158. e-ISSN: 1699-7468. DOI: 10.1344/cercles2020.23.1012. 
caso del Diario, el malvado protagonista suele ser un líder obrero socialista que vive opíparamente a costa de engañar a sus compañeros, a quienes utiliza para sus propios fines, no importándole los esfuerzos y sacrificios que hacen a causa de sus indicaciones. ${ }^{80}$

Pero, más allá de estas diferencias, los puntos de confluencia de ambas corrientes políticas eran muy importantes, y resultaron decisivos a la hora de articular una movilización conjunta contra las medidas laicistas, lo que permitiría ir generando, de hecho, una identidad católica basada en esos puntos comunes. Ante todo, la defensa a ultranza de la Iglesia como causa suprema para ambos: «Vean ustedes por dónde esa Prensa vocinglera ha hecho sin querer, y en pocas horas, una labor que parecía muy difícil. La labor de despertar el sentimiento católico del país, hasta el punto de unir en un mismo ideal a conservadores y carlistas. El instinto religioso está, pues, en línea de batalla enfrente del instinto antirreligioso». ${ }^{8 \mathrm{I}}$

Ese será el elemento común fundamental y de gran relevancia para el futuro: el nacionalcatolicismo, es decir, la idea de que religión católica y nación española (y Navarra, específicamente) estaban vinculadas de manera indisoluble. Así, quien atacaba a la Iglesia era un mal español (o un mal navarro), idea recurrente en muchos artículos, a veces con referencias historicistas a un pasado mítico, en el que destacaban las grandes gestas de la Reconquista. A través de episodios como la batalla de las Navas de Tolosa se exaltaba un supuesto carácter navarro siempre vinculado a la defensa heroica del catolicismo. Este tipo de referencias se utilizó en gran medida para animar a la participación en las manifestaciones de 1906 y I9Io. Por ejemplo, de cara a la primera, El Pensamiento Navarro apelaba: «Vosotros, por cuyas venas corre, sin desvirtuarse, la sangre de los herederos de las Navas y del monte Tauro, no desoiréis el llamamiento de esa voz de

80 Por ejemplo, en Diario de Navarra, 4/9/1910.

8I El Pensamiento Navarro 28/ıo/ı9o6, recogido de El Correo Español.

Cercles. Revista d'História Cultural, 23 (2020), 119-153.

ISSN: 1139-0158. e-ISSN: 1699-7468. DOI: 10.1344/cercles2020.23.1012. 
lo alto, de esa voz de Dios». ${ }^{82} \mathrm{Y}$, asimismo, de cara a la segunda, el Diario empleaba la participación navarra en las cruzadas: «El día en que podamos mostrar que los católicos navarros llevamos grabado en el corazón el lema de nuestro rey Teobaldo, se acerca [...]. De los siglos todos de la historia de Navarra, pudiera decirse que han llevado como lema el del rey cruzado que asistió a Palestina con la flor y nata de los caballeros navarros entusiasmados todos al grito de ;Dios lo quiere.». ${ }^{83}$

Esa idea de una España cuyo origen está vinculado al catolicismo se corresponde con la de una Navarra que «fue cristiana antes que Cristo», ${ }^{84}$ lo que sería también un nexo entre la visión nacionalcatólica española y la vasca, que se aprecia, por ejemplo, en el discurso de fray Evangelista de Ibero en la catedral de Pamplona en I902, considerado uno de los precursores del nacionalismo vasco en Navarra, ${ }^{85}$ aunque en los años que nos ocupan era todavía un fenómeno muy minoritario. $^{86}$

82 El Pensamiento Navarro, 8/12/1906.

83 Diario de Navarra, 30/9/1910. O, en la misma línea, El Pensamiento Navarro, 2/Io/I9Io.

84 El Pensamiento Navarro, 2/10/1906.

85 En este discurso, antiliberal y teocrático, animaba a la unión de todos los católicos vascos bajo la bandera de la religión y de la raza vasca, dejando a un lado las cuestiones terrenales como las dinásticas por las cuales atacaba directamente a carlistas y conservadores. Insistía en la idea de pureza de la raza vasca y su relación desde su origen con el cristianismo. En 1906 escribió el Ami Vasco, un catecismo sobre el nacionalismo vasco basado en la obra de Sabino Arana. A. Martínez-Peñuela Vírseda, Antecedentes y primeros pasos del nacionalismo vasco en Navarra: 1878-19I8, Burlada, Gobierno de Navarra, 1989, pp. 38-47.

86 En la primera década del siglo $\mathrm{xx}$, aunque el carácter culturamente vasco de $\mathrm{Na}$ varra estaba bastante aceptado, el recién creado PNV apenas estaba asentado. Hasta I910 no se creó el primer batzoki en Pamplona, y hubo que esperar a la siguiente década para que su presencia tuviera más fuerza, lo cual, en parte de la derecha navarrista, cambió la percepción sobre el vasquismo cultural que se había mantenido hasta entonces. A. GARCíASanz Marcotegui, Historia del navarrismo (I84I-I936). Sus relaciones con el vasquismo, Pamplona, UPNA, 2002. 
Y en esa esencia navarra, junto a la religión, ambos medios situaban también los fueros. Aunque con diferencias entre la posición cuarentayunista (partidaria el orden salido de la Ley de Modificación de Fueros de I84I) del Diario de Navarra y la defendida por los carlistas de reintegración de los antiguos fueros (cuestión que adquirirá mayor relevancia en la próxima década), ambos periódicos coinciden en la defensa de un régimen foral. ${ }^{87} \mathrm{Y}$, como vimos, ese foralismo estuvo muy presente tanto en la manifestación de 1906 como en la de I9IO, con el Monumento a los Fueros y el recuerdo de la Gamazada en un papel destacado.

Son frecuentes, tanto en el Diario como en El Pensamiento, expresiones del tipo «Navarra católica no puede permitir » o «Unidos todos los navarros en defensa de...», en una sinécdoque habitual que suponía presentar la parte clerical (mayoritaria pero parte) como la totalidad, negando así el carácter de navarros a liberales, republicanos, socialistas, anarquistas, etcétera, sin los cuales no se explicarían muchas cosas que la propia prensa católica denunciaba que ocurrían en la Pamplona de entonces: cánticos de la Marsellesa o del himno de Riego, vivas a la república, asistencia a obras denostadas como Electra, mítines republicanos, enfrentamientos callejeros En esos casos, la respuesta era sencilla: esos incidentes o los provocaban elementos foráneos o, en todo caso, eran malos navarros contaminados desde el exterior.

Así, por ejemplo, en 1905 , el entonces todavía director del Diario, Eustaquio Echauri, en un artículo en el que defendía a unos profesores del seminario díscolos con el obispo, decía que «les ha-

87 De hecho, la defensa de los fueros era un elemento común a casi todas las fuerzas políticas navarras, si bien con matices importantes sobre el concepto que se tenía de ellos. Para más información se pueden consultar A. García-SAnz Marcotegui, I. Iriarte López y F. Mikelarena Peña, Historia del navarrismo (I84I-1936). Sus relaciones con el vasquismo, Pamplona, UPNA, 2002; y A. García SAnz Marcotegui, La identidad de Navarra. Las razones del navarrismo (I866-1936), Pamplona, Gobierno de Navarra, 2012.

Cercles. Revista d'História Cultural, 23 (2020), 119-153. ISSN: 1139-0158. e-ISSN: 1699-7468. DOI: 10.1344/cercles2020.23.1012. 
bían de declarar la guerra a muerte los palaciegos aduladores, no navarros unos, navarros espurios los otros; $y$ antinavarros, todos ${ }^{88} \mathrm{Y}$ ante los incidentes ocurridos tras la manifestación católica de 1906, como no se podía concebir que unos navarros se comportaran así, el Diario de Navarra se apresuraba a "hacer constar que en las turbas desarrapadas de la noche del domingo no iba un navarro [...]. Eran advenedizos, gentes venidas de fuera de este bendito país; los mismos que ocasionan las crisis jornaleras [...]. Solamente así se explica que pudiera gritarse impunemente ;Abajo la Virgen del Camino. ${ }^{89}{ }^{89} \mathrm{Y}$, en la misma línea, ante la manifestación organizada por los anticlericales de Pamplona una semana después, también el Diario comentaría que acudieron muy pocos navarros, "porque no era política sino anticatólica, y porque no era navarra»..$^{90}$

Ligado a esto se encuentra la visión maniquea con la que ambos medios tratan la cuestión religiosa. La Iglesia siempre es atacada, los católicos son siempre valientes y honrados ciudadanos que la defienden ante un acto de injusticia intolerable. Por ejemplo, en 1906, el Diario de Navarra publica una noticia sobre unos incidentes en un acto de desagravio en Salamanca. Los republicanos habrían aprovechado que el acto estaba dividido entre hombres y mujeres para atacar a estas, hasta que llegaron los hombres y los expulsaron a golpes. Por la tarde, el casino republicano cerró por miedo a represalias «por temor a que las personas honradas lo asaltasen». ${ }^{91}$ Este tipo de narraciones maniqueas de incidentes en los que valerosos católicos se defienden de una chusma inmoral abundarán en la prensa católica

88 Diario de Navarra, 26/9/1905 (las cursivas son mías). Sobre la demonización del elemento foráneo como algo externo y nocivo en potencia para la comunidad, véase J. Ugarte, La nueva Covadonga insurgente. Orígenes sociales y culturales de la sublevación de 1936 en Navarra y el País Vasco, Madrid, Biblioteca Nueva, 1998.

89 Diario de Navarra, $\mathrm{II} / \mathrm{1} 2 / 1906$.

90 Diario de Navarra, 18/12/1906.

91 Diario de Navarra, 4/12/1906.

Cercles. Revista d'Història Cultural, 23 (2020), 119-153. ISSN: 1139-0158. e-ISSN: 1699-7468. DOI: 10.1344/cercles2020.23.1012. 
de estos años, lo que generará una identidad victimista, e incluso martirial, entre los católicos.

Así pues, quedaba servida la batalla entre el bien y el mal, entre los seguidores de Jesucristo, héroes honrados que defienden la esencia católica de España, y los de Luzbel, villanos indeseables que quieren descatolizar España. Siempre equiparando anticlericales con anticatólicos. Y en el bando de estos, ambos diarios insisten en ver la mano de un complot masónico que estaría detrás de todas las políticas laicistas, que intentaban acabar con la Iglesia en toda la Europa católica. ${ }^{92} \mathrm{~A}$ veces se le suman cómplices tan dispares como judíos, anarquistas, protestantes, librepensadores, republicanos, etcétera. La esencia siempre es masónica, aunque el Diario tenderá a incidir más en la responsabilidad de socialistas y anarquistas, acorde con las preocupaciones de la oligarquía local por la emergencia del movimiento obrero. Así, por ejemplo, poco antes de la manifestación masiva de diciembre de 1906, el diario conservador advierte que hay que evitar lo ocurrido en Francia, donde relaciona las medidas anticlericales con que los anarquistas actúan con total libertad. ${ }^{93}$

Cabe resaltar que, en el caso español, la masonería, con independencia de sus objetivos, no tenía la fuerza suficiente para estar detrás de los movimientos anticlericales. Los responsables de esa movilización anticlerical fueron en gran medida los republicanos. ${ }^{94}$ Sin embargo, la idea de que había una conspiración masónica a nivel inter-

92 Así, en el Diario de Navarra (4/2/1906), se afirmaba que «nada puede imaginarse más abyecto y más vil que el espectáculo de los empleados del Estado francés, masónico y judío, penetrando en las iglesias». O, en El Pensamiento (27/1r/1906), que «el sectarismo hugonote y la ambición británica forman concierto con el judaísmo y la masonería, y juntas estas sectas han establecido un plan internacional y secreto».

93 Diario de Navarra, I3/II/1906.

94 J. De La Cueva, «Movilización política e identidad anticlerical, i898-I9Io», Ayer, 27, 1997, p. 109.

Cercles. Revista d'Història Cultural, 23 (2020), 119-153. ISSN: 1139-0158. e-ISSN: 1699-7468. DOI: 10.1344/cercles2020.23.1012. 
nacional para acabar con la Iglesia en la Europa meridional estaba muy extendida ya desde el siglo pasado. ${ }^{95}$

En cualquier caso, la idea compartida era que subyacía un complot de fuerzas malignas en las políticas laicistas, idea que seguirá muy vigente en el futuro y que tiene relación con otro elemento común: el rechazo a la democracia. En esa lucha entre el Bien y el Mal, la democracia era vista como un peligro. En el caso del carlismo, el rechazo del parlamentarismo liberal es explícito desde su origen. Y en el de los conservadores del Diario, aunque lo acepten dentro de los límites de la Restauración, la preocupación por la progresiva participación social y política de las masas los hará evolucionar hacia posiciones más autoritarias, evolución que se completará en los años posteriores, si bien ya puede apreciarse, por ejemplo, en la respuesta a la Semana Trágica de 1909. ${ }^{96}$ Asimismo, en las páginas del Diario se criticará también de manera abierta a la incipiente democracia cristiana que estaba naciendo en países como Francia, tildándola de herética. ${ }^{97}$

95 Pío IX redactó al menos I45 documentos de condena de la masonería, y León XIII, 228. En el Congreso Antimasónico Internacional, organizado en 1896 en Trento, entre las numerosas adhesiones que se recibieron estuvieron importantes personalidades de la política española, y es reseñable la destacada presencia del carlismo, incluyendo al propio pretendiente D. Carlos. Al año siguiente se destapó el engaño de Leo Taxil, que había ayudado a fraguar la teoría de la relación entre masonería y satanismo, lo que produjo un giro en la antimasonería, que se centró más en su supuesta unión con los judíos (aprovechando polémicas como el caso Dreyfus) y el comunismo. J. A. Ferrer Benimeli, El contubernio Judeo-Masónico-Comunista, Madrid, ISTMO, pp. 39-75 y I24-I39.

96 Sobre esta cuestión y el rechazo conservador a la democracia, entendida como tiranía de las mayorías, véase M. SuÁrez CoRtina, Entre cirios y garrotes. Política y religión en la España contemporánea, 1808-1936, Cuenca, Ediciones de la Universidad de Castilla-La Mancha; Santander, Ediciones Universidad Cantabria, 20I4, pp. II5-I2I.

97 Diario de Navarra, 3/9/1910.

Cercles. Revista d'Històia Cultural, 23 (2020), 119-153. ISSN: 1139-0158. e-ISSN: 1699-7468. DOI: 10.1344/cercles2020.23.1012. 


\section{Conclusión}

El indudable éxito de las manifestaciones católicas de 1906 y 1910 es una prueba de la gran capacidad de movilización que la Iglesia y el movimiento católico habían alcanzado. Tras esa disputa entre clericalismo y anticlericalismo se encontraba, como afirman Louzao y Rodríguez Lago, «un importante mecanismo de nacionalización de los ciudadanos, a través de los diversos dispositivos político-culturales (discursos y movilización política, imágenes y estereotipos, redefinición simbólica, etcétera), que consiguió vehicular e integrar afectiva y emocionalmente las diferentes afirmaciones nacionales tras la crisis de identidad abierta con la pérdida colonial de $1898 \% .9^{98}$ Los católicos no dudaron en utilizar un repertorio moderno adaptado a la nueva sociedad de masas: mítines, manifestaciones, charlas, recogidas de adhesiones, concentraciones, etcétera. $\mathrm{Y}$, en un lugar destacado, la buena prensa católica, cuya difusión de un discurso movilizador basado en la idea de una Iglesia perseguida por un gobierno sectario que iba en contra de la propia esencia de la comunidad nacional fue, sin duda, una de las claves del éxito de la movilización católica. Una prensa que estos años fue adquiriendo un tono cada vez más combativo, porque, como señalaba El Pensamiento Navarro: «El mundo moderno es el mundo de la prensa, la prensa es del que hace más ruido». ${ }^{99}$

Navarra no se quedó al margen de ese proceso que Louzao ha llamado "recomposición religiosa en la modernidad», y, como hemos podido ver, también aquí se vivió, en la primera década del siglo $\mathrm{xx}$, una etapa de fuerte activismo propagandista a través de la

98 J. LouzaO y J. R. Rodríguez, «Religión y nacionalización. Una aproximación desde la Historia española», en F. Luengo y F. Molina (eds.), Los caminos de la nación. Factores de nacionalización en la España contemporánea, Comares, Granada, 20I6, p. 73.

99 El Pensamiento Navarro, Io/o8/1910.

Cercles. Revista d'Història Cultural, 23 (2020), 119-153.

ISSN: 1139-0158. e-ISSN: 1699-7468. DOI: 10.1344/cercles2020.23.1012. 
prensa, que sirvió para forjar una identidad católica militante movilizada con gran éxito en contra de la Ley de Asociaciones en 1906 y, de nuevo, contra la Ley del Candado en riro. A través del análisis de El Pensamiento Navarro y el Diario de Navarra, hemos visto cómo las dos principales corrientes del catolicismo político navarro, el carlismo y el conservadurismo cercano al maurismo, lograron articular grandes movilizaciones unitarias en defensa de los intereses de la Iglesia. A pesar de las evidentes diferencias existentes entre ambas corrientes (en sensibilidad social, estrategia electoral, retórica violenta, etcétera), acabó pesando más su coincidencia en la defensa a ultranza del estatus de la Iglesia, el rechazo de la democracia o la visión maniquea del mundo sustentada en ese nacionalcatolicismo que consideraba a la religión católica la esencia de la comunidad nacional y que implicaba la expulsión de la comunidad de aquel que no compartiera dicha visión, creando así un estado de opinión pública que fue el que permitió esas movilizaciones masivas, que, a su vez, sirvieron para fortalecer una identidad navarra ligada a su papel de vanguardia en la defensa de la catolicidad de España, con un mensaje en el que la defensa de la foralidad era compatible con el nacionalcatolicismo español. Siguiendo el análisis de Coro Rubio para el caso vasco, ${ }^{100}$ esa defensa de los fueros dentro del marco estatal como elemento definitorio y diferenciado, es decir, el regionalismo político, se convirtió en un mecanismo informal de nacionalización. ${ }^{\text {Ior }}$ Para ello son fundamentales los dispositivos político-culturales a los que hemos hecho referencia antes, que necesitan vehiculizarse a tra-

ioo Coro Rubio Pobes, "Centinelas de la Patria. Regionalismo vasco y nacionalización española en el siglo XIX», Historia contemporánea, núm. 53, 20I6, pp. 393-425, y La identidad vasca en el siglo XIX: discurso y agentes sociales, Madrid, Biblioteca Nueva, 2003.

IOI Pero de una nacionalización no homogénea basándose en la interpretación de esos fueros. Actuará como mecanismo de nacionalización española coincidente con el discurso estatal en el caso del liberalismo, con un discurso paralelo en el caso del carlismo y en una nacionalización alternativa en el caso del nacionalismo vasco.

Cercles. Revista d'Historia Cultural, 23 (2020), 119-153. ISSN: 1139-0158. e-ISSN: 1699-7468. DOI: 10.1344/cercles2020.23.1012. 
vés de las esferas de nacionalización. ${ }^{102}$ En este caso concreto, hemos visto cómo la esfera semipública cobra una importancia vital, no solo a través de la prensa, sino también con otra serie de elementos que la acompañan, como las propias manifestaciones, los círculos carlistas, las vigilias nocturnas, acudir a misa, etcétera. Pero esta esfera tiene una gran capacidad de influencia porque se superpone a la esfera privada, hecho de especial relevancia en el caso del carlismo. ${ }^{\text {I03 }}$ Porque, como bien ha afirmado Fernando Molina, en los procesos de nacionalización, el individuo tiene una gran importancia, y su propia experiencia y la adecuación del relato a su realidad son claves para que este triunfe. ${ }^{104} \mathrm{Y}$, en el caso concreto que hemos analizado, la cuestión religiosa con todos los elementos que conllevaba fue básica en la nacionalización de parte de la sociedad navarra.

Y, aunque a partir de la segunda década del siglo xx el conflicto religioso irá quedando en un segundo plano, fundamentalmente debido al mayor protagonismo en los siguientes años de la cuestión social y, más tarde, a la calma forzada por la dictadura de Primo de Rivera, esa cultura política nacionalcatólica seguirá siendo clave en las principales corrientes del catolicismo político. Así se vio en la propia dictadura de Primo de Rivera, cuando la identificación de nación y religión logra una cobertura institucional que contrasta con

IO2 Según Alejandro Quiroga, se pueden establecer tres esferas de nacionalización: la pública, la semipública y la privada. La semipública haría referencia a las instituciones privadas que actúan en el ámbito público. A. Quiroga, «La nacionalización en España. Una propuesta teórica», Ayer, 2013, pp. 17-38.

IO3 Como comenta Jordi Canal, «el carlismo se reproduciría asimismo como una familia, fundiendo lo cultural con lo biológico. La lógica de este discurso convertía en prácticamente imposible que de una familia carlista pudiera surgir otra cosa que carlistas». Y alude a un pasaje de «Paz en la guerra» de Unamuno en la que Doña Mariquita afirmaba sobre el carlismo que «se mama con la leche, y lo que con la leche se mama, en la mortaja se derrama». J. Canal, El carlismo, Madrid, Alianza, 2000, p. 247.

io4 F. Molina Aparicio, «La nación desde abajo. Nacionalización, individuo e identidad nacional», Ayer, 2013, pp. 39-63.

Cercles. Revista d'Història Cultural, 23 (2020), 119-153.

ISSN: 1139-0158. e-ISSN: 1699-7468. DOI: 10.1344/cercles2020.23.1012. 
el repentino cuestionamiento del estatus de la Iglesia que supuso la Segunda República. ${ }^{\text {1os }}$ Será entonces cuando esa identidad católica victimista pero combativa, forjada en la primera década del siglo Xx, se convertirá en uno de los elementos clave en la reorganización de la derecha más radical, que logró amalgamar movimientos políticos diferentes, siendo el aglutinante ideológico fundamental en la movilización contra las reformas republicanas hasta la propia dictadura franquista. Una movilización que de nuevo sería en especial masiva en Navarra, cuando se volvió a reclamar su papel de Covadonga de la nueva reconquista católica ${ }^{106}$ contra un régimen que cuestionaba tanto el estatus de la Iglesia como otras posiciones de poder. Porque, en efecto, la cuestión de si el poder de la Iglesia aumentaba o se reducía no estuvo nunca aislada, sino que se entremezclaba con otras claves, como la idea de nación, el modelo de ciudadanía, los estereotipos de género, el tipo de enseñanza o el propio orden socio-económico. ${ }^{\text {I07 }}$

IO5 A. Quiroga, «La trampa católica. La Iglesia y la Dictadura de Primo de Rivera», A. Botti, F. Montero y A. Quiroga (eds.), Católicos y patriotas. Religión y nación en la Europa de entreguerras, Barcelona, Sílex, 20I3, pp. I6I-I92.

IO6 Véase, al respecto, J. Ugarte, La nueva Covadonga insurgente. Origenes sociales y culturales de la sublevación de 1936 en Navarra y el País Vasco, Madrid, Biblioteca Nueva, 1998, y J. Dronda, Con Cristo o Contra Cristo. Religión y movilización antirrepublicana en Navarra, Tafalla, Txalaparta, 2013.

I07 Sobre cómo se entremezclan esos elementos y su importancia en el futuro, véase R. TRULlÉN, España trastornada. La identidad y el discurso contrarrevolucionario durante la Segunda República y la Guerra Civil, Madrid, Akal, 2016. 